\title{
THE IMPORTANCE OF CAPITAL AND LABOUR IN ANIMAL PRODUCTION
}

\author{
N. WestermarcK \\ University of Helsinki, Department of Agricultural Economics
}

Received April 4, 1971

\begin{abstract}
Technical development in animal production, as in agricultural production in general has a twofold function. The first is to substitute capital for human labour, and the second is to gain a higher yield per animal unit.

Especially in animal production carried on with hired labour, the production factor capital is substituting the production factor labour at an accelerated rate.

In animal husbandry the capital investment in relation to the labour input on modern family farms is, on an average, less than the capital investment in crop husbnadry. At the same time it appears also that on the smaller farms the compared values lie closer to each other, while increasing size of farms leads to a much greater increase of capital investment in crop husbandry than in animal husbandry. capital.

The need of capital occurs for two different purposes: for investments and circulating

The need of circulating capital in relation to the amount of sales (gross return) is $21 / 2$ times greater in milk and beef production than in pork or egg production. In relation to the need of investment capital the demand for circulating capital is particularly great in beef and pork production. The high demand for circulating capital in pork production in relation to the labour input is connected with, among others, the continuous need of large replacements.

At a given labour input the capital investment in relation to sales is considerably higher in milk production than in pork production, while egg production occupies an intermediate position.
\end{abstract}

The points that will be treated here are in the first hand the following:

Substitution of labour by capital on farms concentrating on animal products.

Relationship between labour input and capital input in crop and animal husbandry.

Labour input versus capital input in various branches of animal production.

Capital input versus sales in the different branches of animal production.

Technical development in animal production, as in agricultural production in general, has actually a twofold function. The first is to substitute capital for human labour, and the second is to gain a higher yield per animal unit.

Technical development consists of both biological-technical and mech anical-technical advances. The first mentioned progress group comprises, among others, livestock breed improvement, feeding of livestock, advances in 
veterinary medicine, and other comparable measures. New organization techniques can also be included under biologic-technical development. Mechanic-technical progress admittedly, also contributes to increased yields, but its greatest importance lies in the fact that it saves human labour.

In the biologic-technical phase of development, that is, in a phase that in animal production is characterized mainly by increased yields per animal unit, the structure of the enterprise unit does not undergo any noteworthy changes. On the other hand, in the mechanic-technical development phase, there is heavy pressure for a change in the structural conditions; especially the question of size of the enterprise units becomes topical.

The fact that a farm enterprise concentrating on animal production is able to manage with fewer persons to carry out the work than earlier is due not only to the substitution of capital for labour, but also in part to the circumstance that some of the functions previously performed on farms have now been, so to speak, transferred to industries, chiefly to the food industry but also to the metal industry. Such functions are now performed by transport enterprises, butter and cheese factories, slaughterhouses, and so on. Industrially manufactured machines have to an increasing extent replaced the farmproduced draught animals, which represent a farm produce. Vertical integration can also be considered to be a consequence of technical progress in the field of animal production. It is a well known fact that owing to improved production techniques in this field, giant commercial enterprises - agri-businesses, in other words - can undertake the mass production of, for example, broilers, eggs and pork.

It is as well to remember, however, that the effort to curtail the consumption of labour in animal production is not to be considered an aim in itself. For example in Finland - and I presume the situation is, or rather has been, the same in most European countries - part of the importance of dairy cattle husbandry lies in its ability to provide employment for the farm family. As long as the industrial sectors and the service occupations in a country are not developed sufficiently to absorb the labour power released from farming because of rationalization, animal husbandry and especially dairy cattle husbandry will offer employment opportunities, even if this work is characterized by a relatively low productivity per unit of labour input.

The general trend today is nevertheless for c a pital to substit u t e the labour in put. Capital is necessary to assure the uninterrupted continuity of production and to maintain the already existing production apparatus. Secondly, capital is needed to replace the labour power migrating from agriculture i.e., for new investments. Furthermore, there is a need of capital for the creation of a more satisfactory life, among others by relaxing the tight routine in the tending of livestock.

It has not been possible to find fully comparable investigations based on empirical material that would demonstrate the substitution of labour input by capital in the different branches of animal production during a time sequence of some length.

The author has for a great number of years been in charge of the economic investigations on egg-producing farms in Finland. In 1949 the average number of laying hens per farm participating in the study of profitableness was 190 and the labour consumption 7.1 hours per hen and year. In 1970 the poultry numbers had increased to an average of 726 per farm, while the labour consumption had dropped to 1.8 hours per hen and 
per year. The current value of the assets (buildings, machinery and fowls) per manhour had increased in these 21 years from $\$ 2$ to $\$ 3.45$, expressed at the 1970 parity of Finnish currency. Labour costs amounted to 27 per cent of the production costs in 1949 and to 10 per cent in 1970. (Westermarck 1950, 1971). It is to be noted that this investigation covered table egg production associated with farming and not the big specialised poultry enterprises.

According to HJelm e t a l. (1969) in Sweden, the total capital investments in Sweden per worker converted to full-year basis had increased since the end of the 1930's from $\$ 3870$ to $\$ 19350$. The value of investments in specialized animal production enterprises is considerably higher: for example in specialized pork production it is up to $\$ 96750$ per fullyear worker. A similar high level of investments in relation to the labour force is seen primarily in the chemo-technical industry, which has a high capital requirement.

It would nevertheless be wrong to think that merely an increased use of capital would reduce time consumption and save labour power. As has been observed, for instance, in the studies of the author, it seems that a re-organization of the work schedule will affect a marked reduction in labour consumption (WESTERMARck 1949).

Within family farming, the fact remains, however, that although a distinct tendency towards more capitalintensive operation has become evident, the family farms in Western Europe continue to be primarily labour enterprises.

When we consider agriculture as a whole, the substitution of capital for labour first occurred in the field of crop husbandry. Tractors, harvester combines and other farm machinery have replaced much of the labour input in plant production. Only later did a similar phenomenon take place in a $\mathrm{nimal}$ production; in fact it would seem that it is only in the 1960's that we can seriously speak of the mechanization of animal production. The author assumes the reason to have been that the substitution has had a greater effect in plant production, or at least that it has been easier to mechanize this part of farming.

Very probably it has also been less costly, because the mechanization of animal husbandry cannot be achieved merely by the substitution of labour power by machinery, but it is at the same time, and possibly to a still greater degree, necessary to replace the labour power or to reduce the labour force by investing in buildings and interior building equipment.

Crop production and animal production are both biological productions, but farm livestock are animals that require more individual care and attention than field plants do. This most probably has been partly responsible for the priority given to crop production in the mechanization of farming. Another possibly contributing factor may have been the fact that in an agrarian community the work in the fields is usually carried out by men, while women tend the livestock, and as long as there has been no deficit of women the men have sought to ease in the first hand their own burden.

Especially in animal production carried on with hired labour, the production factor capital is substituting the production factor labour at an accelerated rate. There is a shift in the optimum of profitableness of these factors towards a more labour-extensive and capital-intensive production.

It can be said to be characteristic of an investment that freedom of action is tied for a 
Table 1. Value of agricultural assets per 100 working hours in crop husbandry versus animal husbandry on South-Finnish book-keeping farms in the year 1969.

Size group: hectares of field

Number of farms

Gross return from animal husbandry as per cent of gross return of the farm Labour consumption per farm, hrs.

Per cent of preceding devoted to animal husbandry

Value of assets per 100 hrs:

in animal husbandry,

In crop husbandry, \$

$\begin{array}{cccccc}<10 & 10-20 & 20-30 & 30-50 & >50 & \begin{array}{c}\text { Average } \\ 85\end{array} \\ & 171 & 103 & 90 & 48 & 497 \\ 71 & 75 & 67 & 47 & 40 & 57 \\ 2977 & 3762 & 4392 & 4362 & 6748 & 4156 \\ & & & & & \\ 64 & 65 & 63 & 54 & 53 & 60 \\ 166 & 223 & 280 & 304 & 353 & 261 \\ 192 & 288 & 449 & 601 & 627 & 439\end{array}$

long time ahead when a decision is reached. The decision influences several periods of time. Furthermore, one undertakes to bear expenditures, but also expects to obtain income.

It is of some interest to examine the ratio between invested capital in relation to the labour input in crop husbandry versus animal husbandry on bookkeping farms of various sizes in Finland. Data for the fiscal year 1969 are in the Table 1 (Kirjanpitotilojen tuloksia tiliv. 1969). The table shows that in animal husbandry the capital investment in relation to the labour input on modern family farms is, on an average, less than the capital investment in crop husbandry. At the same time it also appears that on the smaller farms the compared values lie closer to each other, while the in creasing si z e of $\mathrm{far} \mathrm{ms}$ leads to mutch greaterincrease of capitalinvestment in crop husbandrythan in animal husbandry. In the case of animal husbandry the term "assets» includes the current value of buildings, barn inventories and livestock, and in the case of crop husbandry it includes the value of machinery, implements and land improvements. The value of land has not been taken into consideration since its evaluation and its distribution between crop and animal production would be very difficult.

In addition to the assets included in this table and representing what can be called "real investments", it is necessary to have circulating c a pital (umlaufendes Kapital). Principly these are the commodities which change their form in the production process when used once and which undergo direct conversion into products. This group of capital will be discussed later.

With regard to Table 1 , it is naturally not correct to compare the percentage of financial return from animal husbandry with the percentage of labour consumption in animal husbandry, since a very large proportion of the harvest, especially on smaller and medium farms, is converted to animal products before it is marketed.

BLонм (1966) presents data from Germany on the percentage distribution of the costs directly referable to the respective lines of production. These figures are shown in Table 2.

These percentages show, among others, the labour-consuming nature of dairy cattle husbandry, but they also bring out the high proportion of costs due to investments in buildings and equipment.

Likewise it is evident that the percentages of feed costs and replacement costs are of an entirely different order of magnitude in the other lines of production, and this accentuates the need of circulating capital (umlaufendes Kapital). 
Table 2. Composition of direct costs in percent in different

lines of animal husbandry

\begin{tabular}{|c|c|c|c|c|c|c|}
\hline & \multirow{2}{*}{$\begin{array}{l}\text { Dairy } \\
\text { cattle }\end{array}$} & \multirow{2}{*}{$\begin{array}{l}\text { Beef } \\
\text { cattle }\end{array}$} & \multirow[t]{2}{*}{ Hogs } & \multicolumn{2}{|c|}{ Poultry ${ }^{1}$} & \multirow[t]{2}{*}{ Broilers } \\
\hline & & & & altern. 1 & Itern. 2 & \\
\hline Labour & 21 & 5 & 5.5 & 8.5 & 7.5 & 5 \\
\hline Feed & 52 & 64 & 64 & 70 & 57 & 64 \\
\hline Buildings and equipment & 16 & 8 & 4.5 & 9 & 7 & 5 \\
\hline Replacements & 11 & 21 & 24 & 8.5 & 25 & 22 \\
\hline Miscellaneous & \} & 2 & 2 & 4 & 3.5 & 4 \\
\hline
\end{tabular}

${ }^{1}$ Altern. 1 = replacements by purchase of baby chicks.

Altern. 2 = replacements by purchase of pullets.

Compared with the other branches of animal husbandry, the capital in beef cattle production is tied up for a longer time. For this reason beef production is in general concentrated in the hands of farmers who are stronger in capital resources than the smaller farmers whose capital resources are weaker.

Dairy farming is a line of production in which mechanization and rationalization has been slow in Europe. In general the herds are still small and the cow-barns are not up to modern standards. In fact it is only during the past few years that real structural changes have begun to take place.

Without discussing in greater detail the results of various studies of work rationalization (Anttila 1969, Steinhauser 1966), it can be said as a general observation concerning dairy farming that milking operations in mechanized stanchion barns seem to account for almost half of the labour consumption, while feeding and cleaning operations each take up about 20 per cent. In barns with up-to-date equipment two-thirds of the total labour input is consumed in milking operations. It is typical that the substitution of labour by capital is accompanied by a change in the composition of labour consumption so that the share of labour directly connected with the product, milk, is increased.

A similar observation can be made concerning egg production. In an investigation that the author made over 30 years ago on egg-producing farms, the yearly labour consumption was 8 hours per hen, and 18 per cent of this was consumed in handling of the eggs (Westermarck 1939). In the year 1968 the labour consumption was 2 hours and the proportion of handling the eggs was 35 per cent (WestermarcK 1969). In an investigation recently performed by the Farm Employers' Association in Sweden labour consumption was 0.2 hour per hen per year, handling of the eggs requiring 70 per cent of the total labour consumption (SEFAstsson et. al. 1969). This comparison is not perfectly balanced, since the study of the author covered farm poultry series averaging 200 respectively 700 hens while the Swedish study dealt with large series of 10.000 hens.

It thus appears that the more advanced the technical equipment and the higher the capital investment, the greater is the share of total working time that goes into product handling. 
As regards the production of meat of different kinds, it is of course irrelevant to speak of a similar phenomenon, since a growing meat animal can be conceived to be at the same time a means of production and a product.

The author has already referred to the need of capital for two different purposes; the need of capital for investments and the need of circulating capital. An investment is to be regarded as the placing of capital in more durable factors of production while circulating capital is used to cover current needs. In the case of farming, especially of animal production, the drawing of a line between these two kinds of capital is not always as easy as it might seem. This refers particularly to the capital in the form of livestock. Not only can animals in certain branches of animal husbandry (beef, pork and broiler production) be regarded at the same time as a product, a semi-finished product and a means of production, in addition the different kinds of farm animals differ greatly as regards the length of their productive life. The difference between, say, a dairy cow and a broiler is obvious, to cite only two extreme examples.

When we compare the different branches of animal production in their need of capital partly for investments and partly for circulating purposes, the comparison is greatly out of balance if in the one case we consider that the value of the animals represents an investment and in another case that it is circulating capital, even if such a procedure is justifiable in theory.

In the example presented in Table 3 the value of the buildings and machinery is regarded as investment capital. The circulating capital includes, besides the value of the livestock, also the capital needed to cover current expenditure. The size of the circulating capital has been calculated in a standardised manner as a certain percentage of the variable costs (including cost of labour but excluding depreciation of machinery and buildings and the interest costs) in accordance with the standard of performance in farm planning in use in Sweden (Databok för driftsplanering 1968).

Accordingly, in the present situation, the input of circulating capital can be calculated in relation to various other factors, such as labour consumption, sales or investments in buildings and machinery. Such a comparison has been made at the Department of Agricultural Economics, Helsinki University, for the different alternatives of animal husbandry. The result is shown in Table 3 calculated at the present price level in Finland and with modern production technique.

The table shows clearly that the need of circulating capital in relation to the amount of sales (gross return) is $2 \frac{1}{2}$ times as great in the case of milk and beef production (fattening of young cattle for slaughter in combination with milk production) as in the case of pork or egg production. In relation to the need of investment capital, the demand for circulating capital is particularly great in beef and pork production. The high demand for circulating capital in pork production in relation to the labour input is connected among others, with the continuous need of large replacements. The fact that the interval between the cash receipts for the sale of pork is considerably longer than between the monthly cash for eggs and milk, while on the other hand, the rationalization of work in hog raising is far advanced, also accentuates the need of circulating capital in relation to the labour input.

Finally, a table calculated at the Department of Agricultural Economics, Helsinki University, is presented in order to clarify the investment requirements (buildings and 
Table 3. Calculated requirement of circulating capital on efficient Finnish farms in relation to labour input, sales and investments in buildings and machinery in different branches of animal production.

$\begin{array}{cccc}\text { Milk } & \text { Beef } & \text { Pork } & \text { Egg } \\ \text { production } & \text { production } & \text { production } & \text { production }\end{array}$

Circulating capital in \$:

per 1000 manhours

5520

630

12500

620

25400

3740

per $1000 \$$ of sales

470

950

270

200

per $1000 \$$ invested (initial) capital

470

1000

250

Table 4. Initial capital requirement for investment in relation to sales on a family farm with 3000 manlabour hours available per year.

No. of animals yearly

Milk production in stanchion barn

Milk production in closed loose housing barn

Milk production in open loose housing barn

Pork production with conventional system

Pork production with liquid manure disposal

Egg production with floor hens

Egg production with cage hens
Capital requirement in \% of sales

$\begin{array}{rr}37 & 196 \\ 78 & 163 \\ 78 & 94 \\ 1160 & 41 \\ 2500 & 46 \\ 6900 & 79 \\ 7300 & 59\end{array}$

machinery) in relation to the sales (gross return) on an assumed family farm with an available labour power of 3000 manlabour hours. The primary data have been obtained from various sources (Databok driftsplanering 1968, Familjelantbruk och specialiserad storprod. 1967, Odenstad 1969, Westermarck \& Mattila 1969). Since the figures in the Table 4 have been derived from different studies, the results for the various production alternatives are not fully comparable. However, the differences are so evident that it can safely be said that with a given labour input the capital investment in relation to sales is considerably higherin milk production than in pork production, while egg production occupies an intermediate position. The capital requirement is highest for the alternative of milk production in stanchion barn and lowest for pork production with conventional system. 


\section{REFERENCES}

Antrilı, R. 1969. Karjarakennukset tänään. Työtehos. julk. 123, 117 p. Porvoo.

Bцонм, G. 1966. Die Neuorientierung der Landwirtschaft. Zweite Aufl. Stuttgart. 143 p.

Databok för driftsplanering. 1968. Lantbr. högsk. medd. B: 9, 276 p. Uppsala.

Familjelantbruk och specialiserad storproduktion. 1967. Medd. fr. Jordbr. Utredn. inst. 5-67, 119 p. Stockholm.

HJelm, L \& RenBorg, U. \& Ölund, G. 1969. Lantbruksekonomi. 312 p: Stockholm.

Kirjanpitotilojen tuloksia tiliv. 1969. Maatal.tal.tutk.lait. tied. n:o 13. Helsinki 1971. Stenc.

Odenstad, G. 1969. Äggproduktionens ekonomi - företagsekonomiska aspekter. Medd. fr. Jordbr. Utredn.inst. $2-69.58$ p. Stockholm.

Sefastsson, J. \& Frost, G. 1969. Arbetsstudier i burhönsstallar. Skogs- och Lantarbetsgivareför. Tidskr. 6: 35-43. Stockholm.

Sternhauser, H. 1966. Wirtschaftlichkeit und Entwicklungstendenzen der Ridviehhaltung. Vortr. zur Hochschultag. Kiel.

Westermarck, N. 1939. Kanataloustyön taloudellisesta merkityksestä, kanatalouden työnmenekistä ja työkustannuksesta sekä niihin vaikuttavista tekijöistä. Acta Agr. Fenn. 41: 1-180.

—»— 1949. Sambandet mellan lantbruksdriftens mekanisering, arbetsåtgången och dess säsongvariation. Kungl. Lantbr. akad. Tidskr. 88, 2: 125-156.

-»- 1950. Kananmunantuotannon kannattavuus tilivuonna 1948-1949. Siipikarja 6.

—»- 1969. Munantuotannon kannattavuus tilivuonna 1967-1968. Siipikarja 3.

—— 1971. Munantuotannon kannattavuus tilivuonna 1970. Siipikarja 4.

—»- \& Matrla, L. 1969. Maatilasuunnittelun normikirja. Helsinki Stenc. 326 s. + liite.

\section{SELOSTUS}

\section{PÄÄOMAN JA TYÖN MERKITYS KOTIELÄINTUOTANNOSSA}

\section{N. Westermarck}

Helsingin yliopiston maanviljelystalouden laitos

Teknisellä kehityksellä on kotieläintuotannossa kuten maataloustuotannossa yleensäkin varsinaisesti kahdenlainen merkitys nimittäin korvata ihmistyö pääomalla ja mahdollistaa korkeampi tuotos eläinyksikköä kohden.

Nykyaikaisella perheviljelmällä pääomapanos verrattuna työpanokseen on keskimääräisesti alhaisempi kotieläintuotannossa kuin kasvinviljelyssä. Suhdelukujen välinen ero käy suuremmaksi tilakoon suuretessa niin, että pääomapanos suhteellisesti kasvaa voimakkaammin kasvinviljelyssä kuin kotieläintuotannossa.

Vaihtuvan pääoman tarve verrattuna liikevaihdon (kokonaistuoton) suuruuteen on maidon ja naudanlihan (= nuori teuraskarja) tuotannossa $2 \frac{1}{2}$ kertaa suurempi kuin sianlihan tai munien tuotannossa.

Suhteessa investointipääomaan vaihtuvan pääoman tarve on varsin suuri naudanlihan ja sianlihan tuotannossa. Sianlihan tuotannossa on vaihtuvan pääoman tarve myös suuri työpanokseen verrattuna.

Työpanoksen pysyessä tietynsuuruisena on pääomapanos liikevaihtoon verrattuna huomattavasti korkeampi maidon tuotannossa kuin sianlihan tuotannossa munien tuotannon asettuessa välimaille. Pääomantarve on suurin harjoitettaessa maidontuotantoa parsinavetassa ja alhaisin harjoitettaessa sianlihan tuotantoa tavanomaisessa sikalassa. 